\title{
Pandemic Induced Uncertainties, Challenges and Threats to Developing Countries: A Case Study of Pakistan
}

\author{
Mazhar Farid Chishti*, Ambreen Afzal**, Madiha Afzal***
}

\begin{abstract}
The aim of this investigation is about the economic effects of Coronavirus, broadly branded as COVID-19. Since its initiation in China, it has cast-iron a large number of lives of human while living millions in isolate in view of viral diseases. Where it brings significant human affliction, it additionally makes worldwide economic interruptions around the world. It obstructs development and smooth activity of businesses of all kinds which badly hamper the balance of trade, exports, imports; public spending, remittances, capital formation process and financial markets all are in the dangers of COVID-19. The whole world goes through a similar example for example curfews and lockdown of changing degrees leaving markets and working environments dead. It stops income age as well as acquires an extraordinary expense to states while managing with worldwide pandemic in the midst of general wellbeing. Accordingly, its economies effects are all the more distressing and subverting. The economies like Pakistan which is already facing political and economic trials is in intimidating position alongside negative developments are confronting a lack of assets to battle with it not to mention bearing income misfortune.
\end{abstract}

\section{Keywords: Covid-19, Impacts on Developing Countries, Economy of Pakistan}

This Article can be cited as:

Chishti M F., Afzal A., Afzal M., (2020). Pandemic Induced Uncertainties, Challenges and Threats to Developing : A Case Study of Pakistan, Journal of Arts and Social Sciences. VII (2), 126-136..

\footnotetext{
* Correspondence concerning this article should be addressed to Mazhar Farid Chishti, PhD Scholar \& Assistant Professor of finance at Lahore Garrison University, al-farid@lgu.edu.pk

** Ambreen Afzal, lecturer of finance at Lahore Garrison University, ambreenafzal@lgu.edu.pk.

*** Madiha Afzal, lecturer of finance at Lahore Garrison University: madeehaafzal@ Igu.edu.pk.
} 


\section{Introduction}

The commotions of Covid 19 have taken aback the world's economic political and social brass tacks with an eruption of trembles. The hostile shock is massive even worse than the global financial crisis of 2009 and its ripple effects can produce a set of other crises. The burden of that effect is to be felt over the glob but in developing countries the situation is getting worsen where health systems, fiscal resources, and governance issues hamper remedial actions. Infect the world is in middle of twofold crisis which is threating both the health of millions of people and the world economy some analysts contend for breaking up global value chain and reshoring production closer to home.

The current insights show that in excess of 150 states have been contaminated and announced instances of COVID-19 differing from tens to thousands with various ephemeral. As per worldwide wellbeing organizations, the world has a large portion of an affirmative COVID-19 cases causing 23,000 passing up until this point.

Evidently, COVID-19 knows no limits and has revealed in each landmass of the world (Gutiérrez, 2020). The direction of its range is seen indistinguishable in each state yet not many of them replicate possible spear because of specific reasons. After China, Europe turned into the focal point of the pandemic as revealed by the World Health Organization (WHO) whereby Asian states detailed slow moving charts of its extent. Italy, an European state far away from China, revealed victims as equivalent to detailed positive cases in China for example 81,000. The expansion in quantities of patients can likewise change because of contributing elements for instance Italy has truly outstanding and energetic wellbeing frameworks which might prompt test a greater number of patients than different nations yet the size of losses has no avocation (Moulds, 2020).

That is the reason it is appropriate to contemplate why it has been watching an upward direction around the world. The investigation shows various reasons including yet not restricted to make a trip past to China, physical interaction with COVID-19 patients, and mass get-togethers. However, it isn't generally fundamental it would get detailed positive as the development of manifestations characterizes the status. Clinical analysts dread that there may be various individuals with undetected COVID-19 who give the infection to others. They contend that individuals with a solid safe framework can endure the manifestations of COVID-19 and may stay unnoticed. An examination at the Huazhong University of Technology in China uncovers that generally 59\% of contaminated individuals in China stay untested and undetected. This contention abides well the reasons why COVID-19 made its route to the remainder of the world (Wang and Hao, 2020).

\section{Worldwide Outline of Economic Loss}

The COVID-19 in China obstructs worldwide business action beginning from China spread in the whole world. The worldwide effects on the economy are assorted running from misfortune in securities exchanges, misfortune in voyaging and transportation industry, the weight on loan costs, request and flexibly unevenness in wellbeing gear, least market movement, and buyer separation, to discuss the least. Worldwide offer business sectors are likely downturn since the beginning of January this year. Offer business sectors hit hard and frequently smashed in light of frenzy purchasing and buying. Russian drop in oil costs additionally disturbed the monetary market emergency around the world. The FTSE, Dow, NASDAQ and stock share markets have recorded the least benefit since 1987. Because of the weight on business action, different national banks diminished loan costs to keep the business streaming easily. The decrease in loan costs makes acquiring less expensive which thusly helps in enhancing business movement. The Bank of England and US Federal Reserve are significant organizations that help to these measures (OECD, 2020). 
Due to sluggish business action, development possibilities stay dubious. The ascent of the pandemic in China and its overall expansion gambled worldwide development by $1 / 2$ percent. Also, worldwide GDP development is extended to decrease by 5 percent from 2.9 percent to 2.4 percent. What's more, it shakes shopper trust in the market and administrations. The movement business and gracefully chain hit hard in $\mathrm{G}$ 20 economies as they report cross country lockdowns in the midst of COVID-19 as every one of these economies are vigorously reliant and profoundly associated with the economy of China. The movement business is broadly harmed by movement banns as in excess of 100 nations declared banns on travel as individuals are done visiting worldwide for business or occasions. At the point when Japan reported the deferment of Olympics 2020 in the midst of COVID-19 it is relied upon to lose 39 million guests (Talmazan, 2020). Another worldwide industry endured in negative as a result of the worldwide financial emergency and that is the car business. Vehicle deals decrease worldwide as governments declare pointless voyaging. The open frenzy doesn't permit clients to go out for buy. During the primary portion of February, vehicle deals in China dropped somewhere around 92\% (Brown and Jones, 2020).

\section{The circumstance of Developing Economies and Covid-19}

The COVID-19 knows no limits and has advanced the world over leaving a huge number of individuals helpless. Given the spreading design, financial disparities, and social delicacy put more vulnerable areas of the social order into hazard. The sickness is expanding the gap between rich furthermore, poor inside the states and rich and helpless states on the planet. It can possibly offer approach to monetary imbalance that would not have the option to defeat in years to come. It is on the grounds that poor people need to hold up under the financial remarkably washouts out of completely enraptured economies. The new exploration on financial results of COVID-19 uncovers that helpless people are more powerless against contract the infection since they can't accept prudent steps just as incapable to go in isolate without food (Fisher, 2020). Financial difference in the worldwide economy is presenting multiple dangers to creating states which are confronting troubles to take fundamental actions to battle the worldwide contagion. The end is concluded from the previous understanding of plagues like flu which watched high multiplication paces of transmission and mortality. This monetary imbalance bothers the circumstance because of two main considerations, the first is mature age and the other is previous wellbeing foundation. Various worldwide reports propose contagion can be multiple times all the more lethal among lower-pay and center pay social orders. (HRW, 2020) Talking about the wretched state of status of creating and immature economies, information of various lower-pay nations are broken down (Maru, 2020).

\section{Circumstantial investigation of Pakistan}

Besides, one would initially need to endure the current economic obliteration brought about by a worldwide fiasco. The previous the Pakistani government knows about the existing economic challenges it appearances to endure this decline, the better our opportunity of endurance will be. To those in concern or not totally knowing the monetary implications, the measures are now taken by the West-presently the focal point of COVID-19 - may likewise be a solid model for us to receive in our endeavors to help or even restore organizations, or in any event, for it markets to just stay alive.

Pakistan's financial circumstance is confronting a further outer record danger, this time as quick fare misfortunes and approaching home settlements (Al Meezan, 2020). On the off chance that the govt. is successful at this significant crossroads in supporting organizations and industry quickly, not exclusively will the misfortunes rising up out of mechanical shutdowns and disposed of creation be tremendous, yet the subsequent increment in joblessness and hardship will likewise be unmatched. This on the rear of two a long time, with development and financial improvement, best case scenario underneath normal, widespread expansion, and consistently developing paces of joblessness and hardship. Actually a reexamine on the financial strategies has gotten fundamental for all legislatures, including our own. The Preceding Corona' financial circle, there will presently additionally be a new 'After Corona' financial world (Waris et al., 2020). 
There's no good inclination noticeable all around the Pakistan Stock Exchange (PSX), those are exchanging work area since the beginning of March month. Furthermore, everything dropped like a place of cards on Monday (March ninth) when Saudi Arabia proclaimed a cash war against Russia to win the oil pieces of the pie after Putin's sense of self hit US oil makers, as unrefined interest fell down with China, Europe, and the remainder of the globe hacking more diligently in view of COVID-19 spreading.

The Karachi Stock Exchange (KSE) 100 index which is most cited index was down 2106 points just minutes after exchange started and the electrical switch must be actuated to quit exchanging request to diminish the temperatures of the market. Yet, nothing amidst a potential downturn can offer help for an investor. KSE remains at 30,667 which is 20pc down after a lot of strong sell-offs from that point forward, as it went through about fourteen days of amazingly unstable exchange. Actually a public sale off would leave the lacking of liquidity. Deficient income as a result of decreasing request here and there the state with the financial pace of $12.50 \%$ of the national banks would make it hard for organizations to inhale with the Chinese infection by and large around (Monnoo, 2020). The contamination suppers and the representative are either sick or self-isolated (rehearsing social separation). An excess of dependence at European, Chinese, and North American ports will continue burrowing breaks in worldwide exchange (Andani, 2020).

Notwithstanding a decrease in volume, unfamiliar material costs have likewise dropped and are somewhere near 24\% in CY20TD, so esteem included material fares ought to stay under worry for at any rate a couple quarters yet are probably going to recuperate development once things balance out. It ought to be seen that our fares have recouped rivalry and material sums have ascended since the solid devaluation experienced over the most recent few years.

\section{Export Reduction}

On the export side, the material gathering speaks to almost $55 \%$ everything being equal), as the table beneath shows. Cotton Yarn itself represents about 5\% everything being equal, while cotton material records for $9 \%$, knitwear $11 \%$, bed wear 9\%, and readymade articles of clothing a full $10 \%$. Be that as it may, to predict how material fares will passage in Covid19's repercussions, late information out of Bangladesh may be indicative. European and U.S. purchasers including Primark, the spending design chain possessed by Associated British Foods Plc, have all in all dropped about $\$ 1.5$ billion of Bangladesh piece of clothing orders as Covid19 bothers request. Upwards of 1,089 Bangladesh article of clothing production lines have seen orders getting rejected, as per the leader of the Bangladesh Garment Manufacturers and Exporters Association. These retractions are straightforwardly affecting existences of 1.2 million laborers. Bangladesh is a bigger article of clothing exporter than Pakistan, coming in runner up after China, and readymade dress processing plants utilize in excess of 4 million individuals while the business represents $13 \%$ of their GDP. Pakistan's extent is littler yet at the same time. (Shafi et al., 2020).

\section{Consumption Drop}

Consumption drop is the principal point is that disturbances to utilization from Covid19 must be limited, given that it is both the biggest offer (>80\%) of GDP and is the biggest supporter of GDP development. Indeed, even as individuals will be influenced by lockdowns, in any event the basic help components (the purchaser staples) must be continued running. Drawing upon Pakistan Bureau of Statistics (PBS) information in the course of recent years, we may surmise that fundamental utilization things including food, refreshments, lodging, water, and utilities add up to $60 \%$ of family consumption, 28 while transport represents another $8 \%$. Thusly, an entire $2 / 3$ rds of family utilization in Pakistan is of non-optional staples, thus long as the lockdowns don't completely upset these utilization designs, a steady tranche of GDP movement will seek after. In any case, that isn't altogether ensured, especially for transport which will be upset; and admittance to utilization stores will be kept to a base. Accordingly, some level of non-optional 
utilization will be affected, while optional things will surely be shortened. Boss among these abridged classifications will be entertainment and culture (2\%), instruction (3\%), and eateries (5\%), which will absolutely fall since inns, schools, and cafés are consistently shut. Shockingly, social insurance adds up to an irrelevant 3-4\% of month to month utilization consumption, and this is probably going to spike in Covid19 conditions, though to a vague degree. (Aslam \& Sheikh, 2020)

\section{Employment Drop}

Khan et al., (2020) Notwithstanding, regardless of whether utilization of staples remains genuinely steady pivots in enormous part on the joblessness rate, since salary levels will be upset by the joblessness of lockdown movement. Joblessness is ascending because of the Covid19 pandemic in all nations. Late information from the US Labor Department for the third seven day stretch of March 2020 shows that US jobless cases have soar to 3.3 million,30 which was up from simply 0.2 million the prior week. This overshadowed what experts were anticipating to be 1.7 million, implying that agreement evaluations of the greatness were themselves excessively careful; given that the US has authoritatively become the nation with the most elevated number of crown cases. Indeed, the jobless cases from the US are the most noteworthy ever (records being kept since 1967).

This should give a sign of where creating nations are gone to a more terrible degree. As indicated by World Bank Data, $7 \%$ of the Pakistani populace lives on under $\$ 1.90$ per day, however 33\% carries on with on under $\$ 3.20$ per day, and a full $75 \%$ carries on with on under $\$ 5.50$ a day. The example is amplified far and wide, since one in each two individuals on earth lives on under $\$ 5.50$ per day. This information causes us to construe the size of the day by day bet class in Pakistan, which may represent in any event 70 million individuals in Pakistan.

International revealing situated in Pakistan has featured that, in the initial fourteen days of the crown lockdown in Pakistan, numerous day by day wage workers have been returning home basically eager, with however a cut of bread or scone, since there are not landing any humble positions to win from this issue is being amplified in other neighboring helpless nations, for example, India, where the sheer mass of desperation is far more noteworthy and the disparities all the more unmistakable; because of which every day bets are being delivered dejected by the hour. To battle this joblessness emergency, the Pakistani government is starting a boost program that will incorporate payment of 12,000 rupees (\$75) to low-pay workers, influencing an assessing 67 million individuals, which will fall under the following segment of government use $(\mathrm{G})$. Government Expenditure: Stimulus As referenced over, the Government of Pakistan has not stopped in this emergency, and in spite of the entirety of the monetary imperatives referenced toward the start of this paper, started a Rs.1.2 trillion upgrade program (or "alleviation bundle") that will be focused towards the working poor. Government spending will in this manner ascend in the following barely any quarters as distributions and move installments are made that look to lighten the expanding pressures in the public eye's least echelon.

This counter-repeating spending will be the main positive driver of GDP development in the up and coming quarters. However, it will thus bring up two issues: first, is the size sufficient to spike movement and give help? And second, by what method may it sway the financial weight that Pakistan conveys? Information from the Ministry of Finance shows that a generous lump of the current consumptions of the legislature are in intrigue installments on household and unfamiliar borrowing, 40 adding up to $36 \%$ of current uses in 1Q20 and 33\% of absolute uses in that period, while paddling year on year by $12 \%$, well in front of GDP development. Improvement consumptions, for example, the Public Sector Development Program (PSDP), whose assets are being diverted towards battling Covid, sum to only $9 \%$ of complete uses and just seem, by all accounts, to be developing quick because of a precarious year-on-year drop in 1Q19 while being lower in supreme terms than in 1Q18 (Rs. 142 billion in 1Q20 versus 165 billion in 1Q18). 
New getting under the IMF's Extended Fund Facility in 2019, and its attending severity stranglehold, effectively limited the financial space where the nation could move.

\section{Sharp decrease in remittances}

A significant notice ought to likewise be made to Pakistan's "fare of work," for example the settlements earned from abroad. Settlements have given a significant life saver to Pakistan in earlier years, sending generally $\$ 1$ billion dollars for each month for as long as twenty years, topping in FY18 when settlements hit almost $\$ 20$ billion. As far as topographical dissemination, Saudi Arabia has remained the biggest supporter nation with 23.4 percent share followed by UAE (21.2\%), USA (15.6\%), UK (15.4\%) and other GCC nations (9.6\%). Previous universal money related emergencies have squeezed abroad Pakistanis, and Covid19 will be the same. This is especially obvious since numerous diaspora family units involve manual situations in the GCC nations, which rely upon pay from recurrent businesses, especially in development, upkeep, lower-level administrations, and accommodation. At the point when these ventures are bolted away, at that point the work class will feel the spot of joblessness or pay pressure, and that too without the assurance of business protection given their nonpermanent or semi-lasting occupant status. As with the precariat every day bet class locally, the Overseas Pakistani precariat class will confront disturbance in an extended Covid19 lull (Noreen 2020).

\section{Investment \& Capital Formation}

Shamshir et al., (2019) explore the investment and capital formation was at that point on the decay before Covid19 hit, and could be depicted as the survivor of diverse difficulties, including "vitality emergencies, fluctuating [raw material] costs, deficiency of gas flexibly and load concealing, lawfulness circumstance, degrading of Pakistani cash, absence of innovative work (R\&D) establishments, absence of present day gear and hardware and creation costs." For reference purposes, out of the $14 \%$ of GDP that speculation uses speaks to, $10 \%$ is private and $4 \%$ is open speculation, and these extents have been consistent for as far back as five years. Key to the Investment class is the mechanical area, which assumes a critical job in the monetary improvement of any nation. Industry utilizes 24 percent of absolute work power, yet the mechanical division development has stayed quieted in the previous barely any years. In FY19 and it developed by $1.4 \%$ contrasted and $4.9 \%$ in $2017-18$. The Large Scale Manufacturing (LSM) commands the general mechanical division, representing 50 percent of the sectoral share. As for financing specifically, which the help bundle tries to deliver somewhat, it is significant that even pre-March 2020, "since the private area was not getting enough bank financing, it is creating less; and this low creation is hauling down the GDP growth,"

A backbone of Pakistan's capital arrangement roll in the course of recent years was the ChinaPakistan Economic Corridor (CPEC), which is a $\$ 60$ billion foundation situated two-sided upgrade program mutually organized by China and Pakistan as a major aspect of the bigger One Belt One Road Infrastructure. Phase 1 of CPEC was more capital-escalated and brought creation exercises up in a few divisions including development; however Phase 2 (in progress) is one of combining framework and acquiring venture. Notwithstanding the auxiliary issues above, there has been a glaring absence of an "esteem looking for imagination" with respect to neighborhood business people. The centralization of LSMs in the material business has additionally prompted area explicit dangers, since material has represented 8-10\% of GDP in the speculation class in the course of recent years (also its offer in sends out X), and is more than 33\% of the LSM classification regarding volume.48 Textiles were likewise the biggest private division capital consumption (capex) speculators in the current monetary year (with Rs.8.1 billion venture), driven by concessional advance plans, for example, the Long-Term Financing Facility (LTTF). But the legislature was in truth making things harder for the material business of late, since the assortment from deals charge on material items expanded to Rs 2.1 billion when contrasted with Rs 0.6 billion in the earlier year, 
following the end of zero-rating system for the sector. So would the administration's help bundle, which is just digressively centered on modern quality, effectively rescue enterprises. Chaudhry et al., (2020).

Pakistan's imports are marginally different however its fares are restricted, and the net distinction is a proportion of - 2:1 with bigger imports. We may cover imports first in such manner, especially oil, since as of late, the "oil group" 51 of imports have represented 25\% of Pakistan's import bill. In FY19, this added up to $\$ 11.8 \mathrm{bn}$ out of $\$ 44 \mathrm{bn}$, implying that any decrease in the costs of oil imports would be invite alleviation. At present, a Saudi Russian oil value war and contention has started to item's the ware's worldwide price. Predictions are this would decrease the globally designated cost of oil to $\$ 20$ a barrel. This would forecast well for the Pakistani economy, and this is calculated into the model as a cost balanced decrease in the import bill. Besides the oil gathering, apparatus imports additionally comprise a significant import class. Repetitive businesses, for example, those subject to apparatus imports, metal (iron and steel) imports, and material related imports are probably going to fall because of a decrease in technical interest as a component of falling interest for trade related industry and CPEC.

\section{Discussion - Worldwide and Domestic Interventions:}

The pandemic remained under control in many developed countries but in case of developing countries like Pakistan where economic indicators, GDP, interest rate and foreign exchange rate were already not in stable form this pandemic hit badly and economy remain sluggish (Djankov and Panizza 2020). Further small and medium size Industry turns into the verge of collapse due to lack in additional funds (Stubbs et al., (2020). The battle with the pandemic must be the highest need of each state. Since the pandemic is worldwide and its safeguards are widespread, each must endeavor to take important measures. And yet, there are more vulnerable economies that can't meet the expense of the lethal infection. In this manner, it is contended that significant economies ought not to walk out on helpless states for the purpose of humankind. It is on the grounds that these states won't have the option to battle the infection all alone. There are certified feelings of dread. The episode of COVID-19 in these states would demonstrate fatal for their families (Gutiérrez, 2020). WHO is of the view that unanticipated weakness conditions make the multiplication of COVID-19 more likely in this manner fundamental precautionary measures must be applied.

It merits referencing here that all significant economies of the world are now languishing from similar results; underdeveloped nations couldn't stay in seclusion with contact. Thus the reason is social and good obligation of more extravagant states that they should concentrate on the wellbeing arrangement of helpless states. Just by an aggregate exertion, this socially commutable infection can be contained. Simultaneously, if the creating countries are overpowered, there are dangers that the pandemic will seethe on in immature nations (Holt, 2020).

So as to forestall this situation, created nations should concentrate on assisting poor states having delicate essential wellbeing frameworks paying little heed to the way that they are confronting COVID-19 in their own nations, what's more, the US which prompted the conclusion of schools, cafés, films, and other open spots counting parks. Numerous EU nations fixed the fringes to forestall the transmission of dangerous infections (Cherelus and Salcedo, 2020). It is on the grounds that medicinal services offices in many immature states particularly in Africa are profoundly buried in the shortage of assets. The admittance to emergency clinics furthermore, concentrated consideration units has been hazardous even in typical conditions to a degree that reviews guarantee that solitary not exactly $50 \%$ of the populace has a simple way to deal with human services. Now in expansion, these states are cut off with different pandemics like Influenza and others (Fisher, 2020). Under this regretful situation, it would be very simple for COVID-19 to spread furthermore, conceivably be run wild particularly in regions where individuals as of now experience the ill effects of intense deficiencies of clinical offices. Likewise, these states additionally experience the weight of evacuees, trans-fringe wrongdoing, and cataclysmic events restricting their 
capability to manage more pandemics. In these conditions, it is problematic for them to fulfill with WHO standards of self-isolation and social distancing (HRW, 2020). In the same way, there is a need for a universal approach to global health (Fandos, 2020). Obviously in Pakistan, where there are some crucial interventions vital for containing the novel pandemic.

\section{Conclusion}

Clearly, observing, comprising, and moderating the effects of this novel endemic is the high need of states and global associations the same. Just conclusive and opportune strategy mediations and quick activities by wellbeing authorities, Fiscal administrative specialists, Central Banks, and Financial change groups can assume an aggregate job to battle, forestall the infection and balance the financial impacts of COVID-19. State banks are self-ruling bodies have taken the situation seriously and the world that have taken measures to help request and market certainty by disposing of extreme finance related conditions by bringing down loan costs, diminishing getting proportions for family units, little business, and guaranteeing market liquidity. Pakistan has additionally made strides in such manner. It brought down; the interest rate which minimizes the loan cost and diminished the cost of petrochemicals which goes about as a significant fuel to industry and vitality supplies. Administrative and administrative reactions must plan to save money related dependability and banking framework sufficiency while continuing monetary action.

\section{References}

Al Meezan. (2020). COVID-19: A Challenge for World Economy and Pakistan. Al-Meezan Investments.Retrieved April $\quad 19, \quad 2020 \quad$ from https://www.almeezangroup.com/download/miscellaneous/A_Challenge_For_Wolrd_Eco nomy_Pakistan.pdf

Alassar, N. M. H., \& Elshafiye, M. H. M. (2020). Remote Diagnosis of Patients with a Smart Device and Mobile Application for the Prevention of Corona Virus 19. Electronic Research Journal of Engineering, Computer and Applied Sciences. 2 (2020). pp. 1-11

Andani, A. S. (2020). Covid-19 is killing Pakistan's Economy. Economic Times Blog. Retrieved April 30, 2020 from https://economictimes.indiatimes.com/blogs/voices/covid-19-is- killingpakistans-economy/

Aslam, H., \& Sheikh, N. (2020). Impact assessment of COVID-19 on Energy and Power Sector of Pakistan.

BCC. (2020). BCC forecast: Coronavirus could further weaken UK economy. British Chambers of Commerce. Retrieved April 21, 2020 from https://www.britishchambers.org.uk/news/2020/03/bcc-forecast-coronavirus-could- furtherweaken-uk-economy-3

Brown, D., \& Jones, L. (2020). Coronavirus: A visual guide to the economic impact. BBC News. Retrieved April 21, 2020 from https://www.bbc.com/news/business-51706225

Chaudhry, R. M., Hanif, A., Chaudhary, M., \& Minhas, S. (2020). Coronavirus Disease 2019 (COVID19): Forecast of an Emerging Urgency in Pakistan. Cureus, 12(5).

Cherelus, G., \& Salcedo, A. (2020). Coronavirus Travel Restrictions, Across the Globe. The New York Times. Retrieved April 21, 2020 from https://www.nytimes.com/article/coronavirus- travel- 
restrictions.html

coronavirus.CNN Business. Retrieved April 20, 2020 from

https://edition.cnn.com/2020/03/04/economy/china-services-employment-

coronavirus/index.html

Djankov, S., \& Panizza, U. (2020). COVID-19 in developing economies. Centre for Economic Policy Research.

Elabiyi M. O., Adenola O. J. (2020). Overview of COVID -19 and way forward. Electronic Research Journal of Engineering, Computer and Applied Sciences. 2 (2020). pp. 28-36

Fandos, N. (2020). Trump Seeks $\$ 500$ Billion in Checks for Taxpayers. The New York Times - Breaking News, World News \& Multimedia. Retrieved April 21, 2020 from https://www.nytimes.com/2020/03/18/us/politics/donald-trump-coronavirus-trumpstimulus.html

Fisher, M. (2020). As Coronavirus Deepens Inequality, Inequality Worsens Its Spread. The New York Times. $\quad$ Retrieved April 22, 2020 from https://www.nytimes.com/2020/03/15/world/europe/coronavirus-inequality.html Foreign Policy. Retrieved April 20, 2020 from https://foreignpolicy.com/2020/03/16/marketcollapse-fears-global-recession-coronavirus-pandemicl

Gutiérrez, P. (2020). Coronavirus map: how Covid-19 cases are spreading across the world. The Guardian. Retrieved April 18, 2020 from https://www.theguardian.com/world/nginteractive/2020/mar/25/coronavirus-map-how-covid-19-cases-are-spreading-across-the- world

Holt, E. (2020, March 27). Why Rich Countries must Protect Developing Nations from Coronavirus Pandemic. Inter Press Service | News and Views from the Global South. Retrieved April 20, 2020 from https://www.ipsnews.net/2020/03/rich-countries-must- protect-developing-nationscoronavirus-pandemic/

HRW. (2020). US: Address Impact of Covid-19 on Poor. Human Rights Watch. Retrieved April 20, 2020 from https://www.hrw.org/news/2020/03/19/us-address-impact-covid-19-poor https://www.pressenza.com/2020/03/coronavirus-pandemic-china-and-cuba-sendmedical-teams-equipment-and-medicine-to-countries/

Jacob, O. N. (2020). Effects of COVID-19 Schools Close Down on Academic Programme of Senior Secondary Schools in Abaji Area Council of Federal Capital Territory Abuja, Nigeria. Electronic Research Journal of Social Sciences and Humanities 2 (II), pp. 84-94

Jacob, O. N., Abigeal, I, Lydia, A. E. (2020). Impact of COVID-19 on the Higher Institutions Development in Nigeria. Electronic Research Journal of Social Sciences and Humanities 2 (II), pp. 126-135

Jegede, D. (2020). Perception of Undergraduate Students on the Impact of COVID-19 Pandemic on Higher Institutions Development in Federal Capital Territory Abuja, Nigeria. Electronic Research Journal of Social Sciences and Humanities 2 (II), pp. 211-222.

Khan, M. F., Ali, S., \& Aftab, N. (2020). The Coronomics and World Economy: Impacts on Pakistan. Electronic Research Journal of Social Sciences and Humanities, 2.

Hällfors, M. H., Antão, L. H., Itter, M., Lehikoinen, A., Lindholm, T., Roslin, T., \& Saastamoinen, M. 
(2020). Shifts in timing and duration of breeding for 73 boreal bird species over four decades. Proceedings of the National Academy of Sciences, 117(31), 18557-18565.

Malik, M. (2020). PM announces record economic relief package. The Nation. Retrieved April 23, 2020 from https://nation.com.pk/25-Mar-2020/pm-announces-record-economic relief- package

Maneesh P, Alaoui, A. (2020). How Countries of South Mitigate COVID 19: Models of Morocco and Kerala, India. Electronic Research Journal of Social Sciences and Humanities 2 (II), pp. 16-28

Maru, D. (2020). Coronavirus is coming for the world's poor. Here are six ways to help. World Economic Forum. $\quad$ Retrieved April 20, 2020 from https://www.weforum.org/agenda/2020/03/coronavirus-least-developed-countries- response/ medicine to countries. Retrieved April 20, 2020 from https://www.oecd.org/berlin/publikationen/Interim- Economic-Assessment-2-March-2020.pdf

Monnoo, K. (2020). COVID-19; Economic Fallouts \& Solutions. The Nation. Retrieved April 20, 2020 from https://nation.com.pk/25-Mar-2020/covid-19-economic-fallouts-solutions

Moulds, J. (2020). People with mild or no symptoms could be spreading COVID-19. World Economic Forum. Retrieved April 23, 2020 from https://www.weforum.org/agenda/2020/03/people-with-mild-or-no-symptoms-could-bespreading-covid-19/

Moulds, S. (2020). Scrutinising COVID-19 laws: An early glimpse into the scrutiny work of federal parliamentary committees. Alternative Law Journal, 1037969X20946990.

Narware, A. (2020). COVID -19: Social Aspects and Responsibilities. Electronic Research Journal of Social Sciences and Humanities 2 (II), pp. 40-44

Nasir, M. S., Khan, M. R. (2020). The Corona virus Pandemic: Symptoms, Precautions and Preventions in the Light of Teaching of Islam. Electronic Research Journal of Social Sciences and Humanities 2 (II), pp. 45-66

Noreen, N., Dil, S., Niazi, S., Naveed, I., Khan, N., Khan, F., ... \& Kumar, D. (2020). COVID OECD. (2020). Corona-virus: The World Economy at Risk. OECD Interim Economic Assessment. Pakistan. Electronic Research Journal of Social Sciences and Humanities, 2.

Pressenza. (2020). Coronavirus pandemic: China and Cuba send medical teams, equipment and Sansa, N. A. (2020). The Correlation between COVID-19 Confirmed and Recovered Cases in China: Simple Regression Linear Model Evidence. Electronic Research Journal of Social Sciences and Humanities 2 (I), pp. 121-129

Sansa, N. A. (2020). The Impact of COVID -19 On Financial Markets: Evidence from China and USA. Electronic Research Journal of Social Sciences and Humanities 2 (II), pp. 29-39

Shafi, M., Liu, J., \& Ren, W. (2020). Impact of COVID-19 Pandemic on Micro, Small, and MediumSized Enterprises operating in Pakistan. Research in Globalization, 100018.

Shamshir, M., Rehman, N. A., Hussain, A., \& Sabir, S. (2019). Relationship among Economic Growth and other Macroeconomic Variables: A Study of Pakistan. Journal of Resources Development and Management, 54, 60-68. 
Singh, J., Singh, J. (2020). Corona Virus and Its Impact on Society. Electronic Research Journal of Social Sciences and Humanities 2 (I), pp. 168-172

Stubbs, T., Kring, W., Laskaridis, C., Kentikelenis, A., \& Gallagher, K. (2020). Whatever it takes? The global financial safety net, Covid-19, and developing countries. World Development, 137, 105171 .

Subacchi, P. (2020). This is how the Coronavirus is affecting Italy's economy. World Economic Forum. Retrieved April 20, 2020 from https://www.weforum.org/agenda/2020/03/italy- coronaviruseconoic-slow-down-virus-outbreak

Talmazan, Y. (2020). Tokyo 2020 Olympics Postponed over Corona Virus Concerns. NBC News. Retrieved April 21, 2020 from https://www.nbcnews.com/news/world/tokyo-2020- olympicspostponed-over-coronavirus-concerns-n1165046

The Nation. (2020). Pakistan reports 10th coronavirus death, fourth in Punjab. Retrieved April 20, 2020 from https://nation.com.pk/27-Mar-2020/pakistan-reports-10th-coronavirus- death-fourth-inpunjab

The News. (2020). Chinese help to Pakistan to fight corona arrives. The News International. Retrieved April 20, 2020 from https://thenews.com.pk/print/635770-chinese-help-to- pakistan-to-fightcorona-arrives

U. P., Essien, M. O., Ukpong, E. S. (2020). Assessment of Nigerian Television Authority (NTA) Ongoing Programme Awareness Campaigns on Corona Virus in Nigeria. Electronic Research Journal of Social Sciences and Humanities 2 (I), pp. 130-141.

Wang, C., \& Hao, X. (2020). Evolving Epidemiology and Impact of Non-pharmaceutical Interventions on the Outbreak of Coronavirus Disease 2019 in Wuhan, China. medRxiv. Retrieved April 23 , 2020 fromhttps://www.medrxiv.org/content/10.1101/2020.03.03.20030593v1

Waris, A., Khan, A. U., Ali, M., Ali, A., \& Baset, A. (2020). COVID-19 outbreak: current scenario of Pakistan. New Microbes and New Infections, 100681.

Woodhouse, A. (2020). Coronavirus: Dollar stores, Clorox make short list of stock winners amid rout - as it happened. Financial Times. Retrieved April 22, 2020 from https://www.ft.com/content/f3db4bfeed33-3300-80ea-c0fdfd2dc7e7 